УДК 821.163.41.09:398

https://doi.org/10.18485/msc50.2019.1.ch15

\title{
Лазар Чурчић
}

\section{ОБРЕТЕНИЈЕ ГЛАВЕ КНЕЗА ЛАЗАРА СЛЕПИЦЕ ИЗ ГРГУРЕВАЦА}

1.

Антологичари нису били наклоњени гусларској песми Обретеније главе Кнеза Лазара. Међу антологијске песме нису је уврстили Бранко Водник, Војислав М. Јовановић, Светозар Матић, Веселин Чајкановић, Војислав Ђурић и Милорад Панић Суреп. Чини се да је песму уврстио у своју Антологију народне поезије само Винко Витезица ${ }^{1}$. Обретеније није доспело ни у све збирке косовских песама. У такве збирке нису је уврстили, на пример, Тихомир Остојић и Војислав Ђурић². Тихомир Остојић је јамачно није држао косовском песмом а Ђурић је имао бољих песама за ограничени простор. Ни у популарним календарима за народ до другог светског рата није било места за ту песму. Према првој књизи Библиографије српских алманаха и календара Миодрага Матицког, у којој је регистрована трећина тих публикација, песма је објављена само у календару Банаћанин за 1902. годину․․

Обретенију главе Кнеза Лазара били су знатно више неклоњени преводиоци. Само две године пошто је Вук 1823. објавио песму, Талфјева је, 1825, превела песму на немачки ${ }^{4}$. Песму је две године потом 1827, на енглески превео Џон Бауринг5. Са немачког је песму 1836. превела на

${ }^{1}$ Антологија народне поезије приредио Винко Витезица, Београд, 1937, 317-319.

2 Косово, народне песме о боју на Косову 1389. године. За народ и школу приредио Тих. Остојић, Нови Сад, 1901. = Народне јуначке песме преткосовске u косовске. Приредио др Војислав Ђурић, Београд, 1954, 1958, 1960.

3 Миодраг Митицки, Библиографија српских алманаха и календара I, Београд, 1986, бр. 125, стр. 188.

4 Голуб Добрашиновић, Библиографија списа Вука Карацића. = Сабрани спиcu, књига 36, Београд, 1974, бр. 199, стр. 127.

${ }^{5}$ Исто, бр. 208, стр. 129. 
француски Елиза Војар 6 . Талфијин превод објављен је и $1835 .^{7}$ и 1853. године ${ }^{8}$.

Између 16. фебруара и 19. марта 1841. држао је велики пољски песник Адам Мицкијевич предавања о српскохрватској поезији усмене предаје на Колеж де Франсу у Паризу и једном приликом говорио и о Обретенију главе Кнеза Лазара9. После извесног затишја, песму је 1868. поново превео на француски Адолфо д Аврил ${ }^{10}$.

Аврил је 1868. објавио дванаест косовских песма и тиме започео њихово објављивање у циклусу. Није јасно због чега, он је из свога циклуса изоставио песму Смрт мајке Југовића. Стојан Новаковић је нашао да је фрнацуско издање косовских песама толике вредности да га је ваљало приредити и за читаоце српскохрватског језичког подручја, те је $1871^{11}$. објавио исти избор, чак и без Смрти мајке Југовића ${ }^{12}$. Следећа издања његових косовских песама објављивана су 1872. у Загребу, 1876. у Београду, 1877. у Загребу, 1882. и 1883. у Београду ${ }^{13}$, 1906. у Загребу ${ }^{14}$ и те године у Београду ${ }^{15}$.

У свим тим издањима објављивао је Новаковић Обретеније главе Кнеза Лазара са нешто исправака. У десетом стиху исправио је прву реч Греота у Греохота. Двадесет и четврти стих: Од удава Скопльа бела града изменио је стихом: Од убава Скадра на Бојани. У 33. стиху уместо и дао је $u x$. У 36. стиху уместо месечине дао је мјесечине. У 48. стиху уместо заити дао је захити. Најзад, у последњем стиху заменио је последњу реч сиротиюскије са сиротиюскијех.

У жељи „да песме да у целини као Стојан Новаковић” превео је његову збирку косовских песама на мађарски и са својим предговором обја-

${ }^{6}$ Исто, бр. 209, стр. 135.

7 Исто, бр. 210, стр. 136.

${ }^{8}$ Исто, бр. 220, стр. 145.

9 Крешимир Георгијевић, Српскохрватске народне песме у полькој книжевности, Београд, 1936, 115.

${ }^{10}$ Ср. Ј. Стојковић, Косовска епопеја. Преглед покушаја за састав народног епа о боју на Косову, Београд, 1901, 75-6.

${ }^{11}$ Стојан Новаковић, Предговор. - Српске народне пјесме о боју на Косову, десето на ново попуњено издање с новим предговором, Загреб, (1906), 3.

12 Исто.

13 Библиотека Матице српске II 14.601.

${ }^{14}$ Ст. Новаковић, Предговор, 3.

${ }_{15}$ Народна библиотека Србије, Каталог книга на језицима југословенских народа 1868-1972, VII, Београд, 1981, 338. 
вио 1882. у Сомбору Ђерђ Радич ${ }^{16}$. Радич је своју збирку начинио према првом, београдском, издању из 1871. или другом, загребачком, из 1872. у којима није било Смрти мајке Југовића, па је ни он није унео у мађарско издање. Колико се Радич држао Стојана Новаковића показује и то што је из његове збирке пренео и измењен 24. стих са поменом „Скадра на Бојани” уместо „Скопља бела града”. Од Новаковића је Радич преузео и податке о преводима косовских песама Сигфрида Капера, Бесонова и д Аврила ${ }^{17}$.

У време када је 1877. штампано четврто издање Новаковићевог Косова објавио је у Загребу Армин Павић Народне пјесме о боју на Косову, али није у тај циклус уврстио и Обретеније главе Кнеза Лазара ${ }^{18}$.

Слично Павићу, држећи се његовог избора, али и допунивши циклус, објавила је Елодија Мијатовић 1881. у Лондону свој избор и превод косовских песама без Обретенија ${ }^{19}$.

Косовске песме објавио је у Бечу 1885. на немачком и Карл Гребер и у свој избор укључио и Обретеније главе Кнеза Лазара ${ }^{20}$.

У времену до првог светског рата објавио је најопширнији избор косовских песама и Срета Ј. Стојковић ${ }^{21}$. Та је збирка прештампана 1906. у издању Српске књижевне задруге, 1913. у издању Матице српске, 1917. у Женеви и 1927. у издању Геце Кона ${ }^{22}$. Стојковић је у свој циклус уврстио и Обретеније као двадесету, последњу, песму. И Стојковић је начинио измене у Обретенију. Задржао је, додуше, 24. стих од Вука, па се и тиме одвојио од Стојана Новаковића, али је уместо четири стиха, 74-77, Гргуревачке Шљепице:

Ил Опову, или Крушедолу, Ил ће Јаску, или Бешенову, Ил Раковцу, или Шишатовцу, Ил ће Ђивши, или Кувеждину,

16 Rigómezei Dalok Radics Györgytöl, Zombor, 1882.

17 Исто, 16.

18 Ср. Ј. Стојковић, Косовска епопеја, 52-3.

19 Исто, 99-103.

20 Исто, 103-104.

21 Лазарииа или Бој на Косову. Народна епопеја у 20 песама. Из народних песама и њихових одломака саставио Ср. Ј. Стојковић, Београд, 1903, 240-1.

22 Народна библиотека Србије, Каталог XII, Београд, 1986, 308. 
дао своју конструкцију од осам стихова:

Ил ће Жичи, или Студеници, Или Пећи, или Дечанима, Ил ће Петци, или ће Павлици, Ил Петровој цркви под Пазаром, Ил у Бањску, или Милешевку, Ил у Призрен Аранђела цркви, Да или ће у Вилиндар свети.

Овом заменом Стојковић је песму начинио логичнијом, али је нарушио јединство песме записане од Слепице из Гргуреваца. У њеној песми постоји јединство простора. Сви манастири из њене песме су са западног дела Фрушке Горе, а Стојковићев простор је од Жиче до Хилендара и сасвим занемареног простора северно од Саве и Дунава, па чак и врдничке Раванице у којој је тада био кивот са моштима Лазаревим.

Једанаест издања Новаковићевог Косова и пет издања Стојковићеве Лазарице до другог светског рата, бројна издања друге књиге Вукових Народних песама, као и друга издања косовских песама ${ }^{23}$ учинили су да је песма, ипак, постала позната и најширем кругу читалаца косовских песама код нас, ако је понекад до њих долазила и измењена.

Чак три превода Обретенија на немачки, те преводи на енглески, француски и мађарски пружају доказе да је песма прешла границе српскохрватског подручја и да је постала део опште духовне баштине. А песма то одиста заслужује. Забележена је од доброг певача, једног од најбољих, изузетних је песничких вредности, а и њен мотив је веома редак, можда и усасмљен.

2.

И поред тога што је Обретеније главе Кнеза Лазара по много чему антологијска песма, у науци је бележена тек узгред. Чини се да је песму у науци први поменуо Стојан Новаковић 1878. године. Он је тада указао да стихови о Лазаревом опредељењу да буде сахрањен у Раваници имају историјску основу у Лазаревој повељи манастиру ${ }^{24}$.

${ }^{23}$ На пример: Српске народне песме - Косово - Избор и белешке Милорад Живанчевић, Београд, 1959, 1964.

${ }^{24}$ Стојан Новаковић, Српске народне песме о боју на Косову. Критичка студија - поводом књиге „Narodne pjesme o boju na Kosovu 1389. Sastavio u cijelinu Armin Pavić..., Годишњица Николе Чупића, Година II, Београд, 1878, 113. 
Томо Маретић је 27 (15) липња (јуна) 1889. читао на свечаној седници у Југославенској академији знаности и умјетности у спомен Видов дана 1389. студију: Косовски јунаци и догађаји у народној епици у којој се задржао и на Обретнију главе кнеза Лазара. Рекао је да је песма „полународна - полуцрквена” и да је на њене „сигурне историчке чињенице упозорио С. Новаковић"25.

И Андра Гавриловић се 1912. држао Стојана Новаковића када је писао да се Обретеније делимично ослања на књижевни извор, повељу Лазареву Раваници ${ }^{26}$.

Јаша Продановић је 1932. тумачио да је тело Кнеза Лазара остало „нераспаднуто четрдесет година” а тада му је глава одлетела к телу и он се посветио (Обретније главе Кнеза Лазара)” због юегових „богоугодних дела... за хришћанску веру". ${ }^{27}$

Драгутин Костић је потом, 1936. нашао да певање о преносу тела Кнеза Лазара са Косова у Раваницу из писама-хроника има и „познато Обретеније главе Кнеза Лазара" ${ }^{28}$. Никола Банашевић је на то приметио: „Што се тиче Обретенија главе Кнеза Лазара (Вук II, 53) за коју г Костић држи да је 'позна варијанта' песме - хронике о преносу Лазарева тела у Раваницу лако се сваком уверити без великих истраживања да је та песма проста прерада неке светачке легенде, о глави св. Јована по својој прилици. У очуваној форми, Обретеније је свакако из Срема, јер се у песми помињу прецизно осам фрушкогорских манастира. Песма је, врло вероватно, у њиховој близини и настала, у сваком случају нема никакве везе с измишљеним 'песмама - хроникама' о преносу Лазарева тела у Раваницу" 29.

Пре Николе Банашевића, Светозар Матић је 1934. уврстио Обретеније главе Кнеза Лазара међу сремеске песме по томе што се у песми „спомиње осам фушкогорских манастира, што је сасвим природно, кнез

${ }^{25}$ Rad Jugoslavenske akademije znanosti i umjetnosti. Књига 97. У Загребу 1889, $161-2$.

${ }_{26}$ Андра Гавриловић, Историја српске и хрватске книжевности усменог постана, Београд, 1912, 114.

27 Јаша Продановић, Верска осећата у народној поезији. = Нама народна книжевност, Београд, 1931, 119-20.

${ }_{28}$ Драгутин Костић, Поводом књиге г. Н. Банамевића, Циклус Марка Краљевића и одјеци франиуско-талијанске витешке книжевности (...), Српски књижевни гласник (СКГ), Нова серија, књ. 47, св. 3, Београд, 1. фебруар 1936, 202.

${ }_{29}^{29}$ Никола Банашевић, О постанку и развоју косовског и Марковог ииклуса - Поводом чланка г Д. Костића, СКГ, књ. 47, св. 7, Београд, 1. април 1936, 132. 
Лазар је донекле сремски светац, а песму је испевала Слепица из Гргуреваца" ${ }^{30}$. Да је песма сремска поновио је Матић и 1953. године ${ }^{31}$.

Никола Банашевић је 1954. написао да „једино Пропаст иарства српског и Обретеније главе Кнеза Лазара - нарочито друга, у којој се набрајају тачно фрушкогорски манастири - могу се сматрати са много вероватноће, правим сремским песмама. Оне су доиста обојене извесним клерикализмом, који не треба мешати с изражавањем оних једноставних верских убеђења или традиција других косовских песама"з2.

Понајвише је пажње посветио Обретенију 1961. Петар Бакотић. Држећи се Матића, он је прихватио да је Слепица из Гргуреваца „познавала Скопље” и да је онамо путовала „у друштву кириџија”. Њему се чини „да пјевачица није била од рођења слијепа, да је у свијести сачувала много јаких и прецизних визуелних утисака”, јер „ни у једној” њеној песми, „нема осим људског говора ниједног шума или звука, нити једног осјета осим онога који стиже у свијест преко очију. Визуелних појава које може спознати слијепац по шуму, по топлини, по опипу, у овој пјесми нема".

Бакотићу се чини да две песме Гргуревачке Шљепице „Пропаст иарства српског и Обретеније главе Кнеза Лазара дјелују као цјелина. У првој је привољење небеском царству, у другој, тако ријећи, санкција те књажеве одлуке вољног избора између испразног свијета и свјетлости посмртног живота. То уједно показује и на истовјетност аутора и на јединство узора, односно изворних легенди, а тај је извор несумњиво средњевековна црквена књижевност. Али и ту има неслагања. Најприје разлика у владарској титули која се даје Лазару: једанпут је цар, а други пут кнез. То је на изглед ситница, али и она треба да има неко објашњење, али засад нека питање остане отворено"з3.

И Владан Недић је прихватио Матићеве разлоге да је Слепица из Гргуреваца познавала Скопље, да је „зацело путовала” правцем „према Нишу и Видину”, да је добро знала „где је Раваница ('Под високом, под

30 Светозар Матић, Сремске песме у Вуковој збирии, Прилози проучавању народне књижевности, Књига I, Година I, св. 2, Београд, новембар 1934, 154.

31 Светозар Матић, Порекло косовских песама кратког стиха, Наш народни еп и наш стих, Нови Сад, 1964, 103, в. Св. Матић, Белешке и објашюень у Вук Стеф. Караџић, Српске народне пјесме, Књига друга, Београд, 1953, 712-4.

${ }_{32}$ Н. Банашевић, С. Матић, Порекло косовских песама кратког стиха (...), Прилози КЈИФ, књ. ХХ, св. 3-4, Београд, 1954, 331.

33 Petar Bakotić, Pogled na ideologiju narodne književnosti, Сплит, 1961, 38-39. 
Кучај - планином')", као што је знала и фрушкогорске манастире и да се „по свој прилици, дуже задржавала на Косову”"

По томе што је писано о Обретенију главе Кнеза Лазара да се закључити да у песми има историјских сведочења и да би могла бити сремског порекла. Усамљена су мишљења Драгутина Костића да су у песми сачувани трагови савремених „песама - хроника” с краја 14. или почетка 15. века; Николе Банашевића да су у песми видљиви трагови клерикализма више него у другим косовским песмама; као и Петра Бакотића да Обретеније и Пропаст царства српског делују као целина. И о њима, али и о онима о којима има више сагласности у науци ће још дуго бити расправа.

3.

У случају лепе и вредне гусларске песме Обретеније главе Кнеза Лазара нема тајни о певачу, одличној Слепици из Гргуреваца, и о записивачу монаху Стефану из Шишатовца, ако би и било корисно да се о њима зна и нешто више. Зна се и да је Вук тражио од Лукијана Мушицког да организује бележење песама Гргуревачке Шљепице, као што се зна да их је учени архимандрит и песник посало у Беч 15/27. децембра 1816. из Шишатовца. Не зна се, и ваљда се никада неће сазнати да ли је Вук и лично упознао Слепицу из Гргуреваца, из села сасвим близу Шишатовца, као што се неће сазнати да ли је од ње и лично записао коју песму, кад је знао да има добрих косовских песама од којих је три држао за посебно вредне. Дабогме да се не зна ни да ли је знао вредност њених песама пре него што му их је Мушицки послао поткрај 1816. године. Извесно је, међутим, да је Вук држао до њених песама када их је упознао. Уосталом како и не би када је од ње добио Пропаст иарства сриског, Косовску девојку, Обретеније главе Кнеза Лазара, Марко укида свадбарину и вероватно Кралевић Марко и соко (Опет то, мало друкчије, Вук II 54), Девојка надмудрила Марка (Вук II 40) и, можда, Мусић Стефан (Вук II 46) ${ }^{35}$.

Обретеније је Вук објавио већ 1823, али у Рјечнику из 1818. нема из ње ни речи ни примера. Да ли би то требало да значи да је онда када је добио песму није држао да је вредна, тешко је рећи. Ваља, међутим, имати на уму да је за њу рекао одмах да је забележена од Слепице из Гргуреваца. Из песме је, пак у другом издању Ријечника, 1852. забележио две речи са два примера:

34 Владан Недић, Слепа из Гругреваца, певач Вука Караџића у Вукови певачи, Нови Сад, 1981, 83.

35 Лаза Чурчић, Слепица из Гргуревац, у штампи. 
Деније

И држаше велика денија у песми 68. стих

Убав

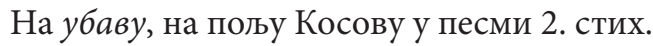

Могућно је да је Обретеније имао на уму када је у Ријечнику 1852. забележио:

Кучај - планина у пјесмама.

Примери из другог издања Рјечника доказ су да је песму користио и после 1818 , ваљда када је припремао да је објави 1823, али можда и касније.

Објављујући Обретеније, Вук га није коментарисао ниједном речи. Прешао је преко тога што се у песми помињу осам фрушкогорских манастира уз Раваницу под Кучајем, а знао је све те манастире добро, и морао је приметити ту нелогичност. Да прећути ту нелогичност јамачно је допринело то што је песма дошла од певача у кога није сумњао, нити је помишљао да сумња.

Вук је добио једну варијанту Обретенија и од Ђорђа Стефановића Којанова, али је није објавио. Учинио је то 1899. Љубомир Стојановић у шестој књизи Српских народних пјесама" ${ }^{36}$. То је фрагмент, који је много слабији од песме коју је певала Слепица из Гргуреваца али у њој има почетак који гусларка није певала.

Једну варијанту Обретенија објавио је Александар Сандић 1861. године ${ }^{37}$. Вук је морао знати и за ту варијанту, али тада, између 1861. и 1864. више није могао да размишља о песми. Сандићева варијанта има почетак као и она Стефановића Којанова, али је нешто дужа. Слаба је и она. Сандић није забележио где је слушао и прибележио песму. Могао ју је слушати и у Банату, одакле је био, али и у Срему камо је одлазио.

Коначно, 1939, објавио је Милош Ђ. Шкорић варијанту Обретенија коју је чуо од бабе Сувајџић у Врднику ${ }^{38}$. Та варијанта је најближа Обретенију Слепице из Гргуреваца. Од ње је, додуше, знатно краћа, али у њој има стихова којих нема, а рекло би се недостају, у запису који је доспео

${ }^{36}$ Српске народне пјесме, скупио их и на свијет издао Вук Стеф. Караџић. Књига 6, Биоград, 1899, бр. 15, стр. 77-8.

37 Glava Lazara knjaza. Vienac uzdraja narodnjeg o Andriji Kačiću Miošiću na stolitni dan preminutja, У Задру, 1861, 137-8.

38 Милош Ђ. Шкарић, Живот и обичаји „Планинаца” под Фрушком Гором, Српски етнографски зборник, Књига 54, Београд, 1939, 160. 
Вуку од Мушицког из Гргуреваца. У врдничкој варијанти нема помена Скопља, Ниша и Видина, али ни фрушкогорских манастира нити Раванице. Кириџије су у њој из Срема, за разлику од песме Гргуревачке Шљепице која је певала само да су кириџије путовале из Скопља, али не и одакле су.

У варијанти Александра Сандића и Ђорђа Стефановића Којанова кириџије се не помињу, али у њима има помена фрушкогорских манастира. Код Стефановића Којанова то су само два манастира:

ил Раковцу, или Шишатовцу

а код Сандића четири:

Јал Раковцу, јали Шишатовцу,

Јал Опови, јали Крушедолу.

Ни у једној од те две варијанте уз помен Раванице не пева се да је то Лазарева задужбина под Кучај - планином као у песми Слепице из Гргуреваца. Ако је судити по сремским кириџијама из врдничке варијанте, о поменима фрушкогорских манастира и изостављеним стиховима о Раваници испод Кучаја, могло би се закључити да је Обретеније сремска песма, односно да је могла настати и у Срему.

Помени Скопља, Кучаја, Ниша, Видина и Косова могли би ићи у прилог Светозара Матића, Петра Бакотића и Владана Недића да је Гргуревачка Шљепица путовала онамо, што би значило да је у песму уткала део властитог сведочења. Томе би се могло додати да је тај пут прешла пре него што је ослепела како то види Петар Бакотић.

Ако је Слепица из Гргуреваца уистину прешли онај пут у време док још није била слепа, онда је она само у Обретеније уградила властито сведочанство о тим просторима. Такво виђење проблема тражи одговор и на питање зашто таква сведочанства није оставила и у другим песмама? Одговор на то питање је и тежак и сложен, а једва да ће моћи да задовољи све и да још буде трајан.

Песме које су доспеле Вуку од Гргуревачке Шљепице све до једне су мотивске песме и све су косовске. Не тако давно ја сам рекао да „она иде у ред оних гуслара, слепаца, професионалаца дакле, која је певање учила и добро научила”. На жалост „нема података како је она певала и ударала уз гусле, те није могућно рећи како је савладала тим најважнијим елементима гусларског певања. Но ако се не зна како је она певала и ударала уз гусле, извесно је да је она текстове које је певала научила беспрекорно и да их је преносила на најбољи могући начин. Чинила је то по цену и да не 
зна речи које је певањем ширила" 39 . То што се у њеном Обретенију нашао парадокс да се уз фрушкогорске манастире поуздано помене Лазарева Раваница под Кучајем, не би морао бити податак да је она интервенисала. Биће пре да је она тако научила песму. Пре ње неко је песми додао уметак са поменом осам фрушкогорских манастира, а други певачи отишли су и даље па изоставили помен Кучај - планине уз Раваницу, као што су испустили и много друго шта.

У Обретенију има још једна нелогичност. Стихови 49-55 казују како је трећи кириџија извадио Лазареву главу, а потом
заити воду у кондиру.
Док се жедни водом обредише,
кад су црној земљи погледали,
неста глава са зелене траве.
Оде глава преко поља сама,
света глава до светога тела,
припоји се како што ј' и била.

Сутрадан, на глас кириџија, окупе се свештеници, владике и четири патријарха да читају молитве. Молитве и бденија читали су три дана и три ноћи, а онда су замолили светитеља да одреди где га ваља сахранити. Кнежева глава се одлучује за Раваницу под Кучајем. Чини се да би тек ту требало да су дошли они стихови о одласку главе своме телу. Ако су, пак, оба места у песми тачна, онда у њој треба видети два извора. Први који би се завршио враћањем Лазареве главе телу пошто су је нашле кириџије, и други који се односи на враћање тела у Раваницу после молитви и бденија. Овај други део могао је настати и независно, могао је бити самостална песма која је касније прикључена првом делу. Да је могло бити две песме могла би бити доказ песма коју је певала баба Сувајџић у Врднику пред други светски рат. У тој песми, наиме нема помена ни фрушкогорских манастира ни Раванице под Кучајем. Овоме ваља додати да први део песме припада класичној митологији, а други део хришћанској.

У разматрању сложености постављеног питања мора се имати на уму да је певач формата Слепице из Гргуреваца умногоме одређен према оном шта пева. Када је реч о жени певачу уз гусле ваља још имати на уму да је она доследнија према ономе што пева, односно што је учила и научила. Такав певач не мења ништа и по томе је насупрот певачима мушкарцима типа Тешана Подруговића, Старца Милије и Старца Рашка, који су у свакој песми и у свакој прилици и певачи и ствараоци. По тим особинама и једни и други певачи, и жене и мушкарци, имају довољно про-

39 Л. Чурчић, Слепища из Гргуреваца, у штампи. 
стора да буду препознатљиви. Слепица из Гргуреваца је препознатљива и по томе што ништа није мењала и што није умела да додаје.

Однос Гргуревачке Шљепице према извору, према наученом и певаном, отклања свако тумачење о њеном додавању из властитог искуства и у Обретенију главе Кнеза Лазара, а то одмах намеће ново питање: да ли је та песма онда сремског порекла. Одговор и на ово питање не може бити коначан. Песма је уистину могла настати и у Срему, али је могла настати и другде. Оно што не би смело да буде спорно то је да је она у традицији усмене предаје несумњиво трајала у Срему тако рећи до јуче. По томе што су многи у њој видели историјске оквире у Лазаревој задужбинској повељи Раваници под Кучајем могао би бити доказ да је песма настала на простору задужбине. И мишљење Петра Бакотића да песма чини целину са Пропасти изарства сриског ишла би у прилог да је Обретеније настало ван Срема, иако Никола Банашевић држи да би обе песме могле бити сремског порекла по односу према изворима из цркве. Такви извори, међутим, могли су бити и у Срему, али и подалеко од њега, свугде где је било култа косовског мученика. Поуздани одговор остаће стога отворен заувек и мораће се прихватити реалност различитог тумачења порекла песме. Њен последњи завичај и њен одлични певач, Слепица из Гргуреваца, задужили су књижевност што су је сачували за сва времена.

4.

Основни мотив Обретенија главе Кнеза Лазара је враћање главе ономе коме је одсечена. Тај мотив је веома редак. Никола Банашевић држи да је тај мотив у песму дошао из хришћанске митологије о светом Јовану Крститељу. У хришћанском миту о св. Јовану Крститељу прича се како се Ирод Антипа, син Ирода убице витлејемске деце, незаконито оженио братовом женом и како је то осудио св. Јован Крститељ. Због тог његовог поступка, Ирод је бацио св. Јована у тамницу. У време једног пира Јовану су одсекли главу и донели је на тањиру. Јованови ученици узели су тело и сахранили. Иродова жена Иридијада, избола је језик Јованов и главу му сахранила на нечасном месту. Једна њена дворкиња ископала је светитељеву главу и сахранила је у Јерусалиму на Гори Јелеонској. Онде је главу нашао један калуђер, да би од тада ишла од руке до руке и била заборављена док је царица Теодора није пренела у Цариград. Са хришћанским митом о св. Јовану Крститељу мит о повратку главе кнеза Лазара слаже се само по одсеченој глави и по томе што су оба светитеља мученици. Све друго у та два мита разликује се. Лазару је, наиме, по пе- 
сми одсечена глава у боју. Када је глава пронађена спуштена је у кладенац где је пронађена после четрдесет година, а онда „оде глава преко поља сама” и „припоји се као што ј' и била”.

Леонтије Павловић је приметио да мит у Обретенију има свој извор у египатском миту о Озирису, али није рекао где је нашао то тумачење ${ }^{40}$, па је могућно да је то његово властито тумачење.

Египатски мит о Озирису одиста има причу о одсецању главе. Главу је одсекао Озирису његов брат, Сет. Тело и глава Озириса бачени су потом у воду, Нил, а спојила их је и оживела га жена Изида уз помоћ сестре Нефтиде. Тај мит слаже се са митом у Обретенију само у одсецању главе, која је потом заједно са телом доспела у воду. Кнез Лазар није доспео у воду са одсеченом главом и телом, а није ни ускрснуо, па ни у миту о Озирису не треба тражити извор мита у Обретенију.

Сасвим је могућно да негде постоји мит сличан оном у Обретенију главе Кнеза Лазара, али га тек ваља наћи. Ако њега нема, онда је он сасвим оригинална и песничка и митолошка творевина. То што у песми постоји и део који по свему припада хришћанској етици може бити само сведочанство да је он христијанизован.

И основни мит из Обретенија и његов хришћански додатак нису никако могли бити производ Гргуревачке Шљепице. Она је учинила све што је могла. На најбољи начин певала је у Шишатовцу за вечност необично и загонетно Обретеније главе Кнеза Лазара. О томе ће се морати водити рачуна, ако то и не буде од најважнијих проблема наше гусларске епике.

5.

Тихомир Остојић, очигледно је, није држао Обретеније главе кнеза Лазара косовском песмом. У томе ваљда и није био сасвим усамљен. Да се песма не мора схватити као косовска може се закључити по томе што се обретеније догодило, песничким језиком речено, четрдесет година после Лазареве погибије. Ако се тих четрдесет година приме искључиво као песничка слика онда ствар постаје одмах мање компликована. Песма је у том случају без сваке сумње косовска.

Да је песма косовска има потврда и у варијантама Александра Сандића и Ђорђа Стефановића Којанова у којима се на почетку пева сасвим одређено о боју на Косову. Тог почетног певања нема у Обретенију Слепице из Гргуреваца нити у варијанти бабе из Врдника. Тешко је пове-

40 Леонтије Павловић, Култови лииа код Срба и Македонаиа, Београд, 1965, 123. 
ровати да је тај део изоставила Слепица из Гргуреваца и баба Сувајџић из Врдника. Биће да је песма до тих двеју певачица доспела без тих правих стихова. Срећом, ти стихови сачувани су у варијантама Александра Сандића, Ђорђа Стефановића Којанова да буду сведочанства да је песма косовска и да отклоне све дилеме о томе проблему.

\section{ОБРЕТЕНИЈЕ ГЛАВЕ КНЕЗА ЛАЗАРА}

\section{(Слепица из Гргуреваца)}

Кад Лазару одсекоше главу на убаву на пољу Косову, од Србља се нико не десио већ се деси једно Туре младо, јесте Туре, ал је од робиње, родила га Српкиња робиња па беседи турско момче младо: „Ао Турци, моја браћо драга, ово j' глава једног господара:

10 греота је од Бога једнога да је кљују орли и гаврани да је газе коњи и јунаци." Узе главу светога Лазара зави у скут коласте аздије,

15 па је носи до воде кладенца, спушта главу у воду кладенац. Стајала је глава у кладенцу лепо време - четрдесет лета. А убаво на Косову тело:

20 ни га једу орли ни гаврани, ни га газе коњи ни јунаци. Мили Боже, на свем' тем вала! Подигле се кириџије младе од убава Скопља, бела града

25 они возе Грке и Бугаре, они иду Нишу и Видину, на Косову конак учинили. Вечерале кириџије младе, вечерале, пак су ожедниле;

30 измеђ' себе вењер ужегоше, ужегоше вењер јасну свећу,
(Баба Сувајџић из Врдника)

Кад Лазару осекоше главу На убаву на пољу Косову, Ty се нико од Срба не треви Окром једно турско момче младо. Јесте Туре, ал од Кауркиюе: Родила га турска робиюица. Ал беседи Туре момче младо:

„Ово ј' глава неква господара „Гриота је и грдна срамота, „Да је кљују орли и гаврани, „Да је газе коњи и јунаци." Па узеде од Лазара главу,

Па је бации у воду кладенца.

Пораниле сремске кириџије,

Па су они јако ожеднили. 
они траже воде по Косову, намера и намерила била, намерила на воду кладенца,

35 један вели кириџија млади: „Ев' у води месечине сјајне.” Други вели кириџија млади: „Није, браћо, месечина сјајна.” Трећи мучи, ништа не беседи,

40 окрену се право ка истоку, па помену Бога истинога, ист'нога Бога и светог Николу: „Помоз, Боже, и оче Никола.” Па загази у воду кладенца

45 те извади из кладенца главу светитеља српскога Лазара па је меће на зелену траву, и заити воде у кондиру. Док се жедни водом обредише,

50 кад су црној земљи погледали, неста глава са зелене траве, оде глава преко поља сама, света глава до светога тела, припоји се као што ј’ и била.

55 Кад ујутру бео дан освану, глас дадоше кириџије младе глас дадоше старим свештеником, и ту дође млого свештеника три стотине стари свештеника,

60 и дванаест велики владика и четири стара патријара: прво пећки, друго цариградски, васељенски и јерусалимски; облачише велике одежде,

65 и на главе капе камилавке, и у руке књиге староставне, па чатише велике молитве, и држаше велика денија

за три дана и три ноћи тавне

70 ни седоше, ни се одморише, ни легоше, ни санка имаше, моле свеца, куд ће светац поћи,
Кад одоше на воду кладенца. Мртва глава плива по кладениу Ал беседе сремске кириџије

„Ово ј' глава неква господара.”

Извадише од Лазара главу,

Метнуше је на зелену траву,

Оде глава преко поља сама,

Она оде код светога тела

Ал доводе сремске кириџије

Доведоше девет свештеника

И до дванајст великих владика,
Па правише велика денија Освећују светога Лазара. 
да којој ће Лаза задужбини:

ил Опову, или Крушедолу,

75 ил ће Јаску, или Бешеновој, ил Раковцу, или Шишатовцу, ил ће Ђипши, или Кувеждину, да или ће у Маћедонију?

Неће светац задужбини туђој,

80 већ он оће својој задужбини, а у своју красну Раваницу под високом, под Кучај планином, што је Лаза саградио цркву за живота јоште за својега,

85 саградио себи задужбину о свом лебу и о своме благу а без суза без сиротињскије.

ГЛАВА ЛАЗАРА КНЕЗА

(Александар Сандић)

Кад се била на Косову војска Па се била за два за три дана. Ал од војске нико не погину; Погинуше до два млада цара:

5 Цар Мурате и кнеже Лазаре. Скакала је Лазарева глава, Скакала је по биелом Врачару, Скакала је за два за три дана:

10 Ту с' не купе орли и гаврани, Beћ се купе отци калуђери, Па облачу велике одежде

15 И читају велике молитве „Казуј јако Лазарева главо, „Казуј јако на коју ћеш страну? „Јал Раковцу, јали Шишатовцу, „Јал Опову, јали Крушедолу,
ГЛАВА КНЕЗА ЛАЗАРА

(Ђорђе Стефановић Којанов)

Кад је била на Косову војска,

Гди су до два цара погинула, Цар Мурате и кнеже Лазаре, Скакала је Лазарева глава, Скакала је по води Ситници,

Да не спазе Турци јаничари.

То зачули оци калуђери Па облаче велике одежде, И на главу капе камилавке, И на руке велико ванђеље: Те читају велике молитве:

Пођи тјело куд си наумило, Ил Раковцу или Шишатовцу, „Јал пребиелој Раваници цркви?” Или оној светој Раваници, Коју јеси саградио Лазо, 
Мртва глава али проговара:

25 „Ни Раковцу, нити Шишатовцу,

„Ни Опову, нити Крушедолу,

„Већ пребијелој Раваници цркви:

„Ту ће моје мировати тиело.”

\section{ОБРЕТЕНИЈЕ ГЛАВЕ КНЕЗА ЛАЗАРА (реконструкција)}

Кад се била на Косову војска, па се била за два за три дана, ал од војске нико не погину, погинуше до два млада иара, иар Мурате и кнеже Лазаре.

(...)

(...)

Кад Лазару одсекоше главу на убаву на пољу Косову, од Србља се нико не десио већ се деси једно Туре младо, јесте Туре, ал је од робиње, родила га Српкиња робиња, па беседи турско момче младо: „Ао Турци, моја браћо драга, ово ј' глава једног господара: гриота је и грдна срамота, да је кљују орли и гаврани, да је газе коњи и јунаци." Узе главу светога Лазара зави у скут коласте аздије, па је носи до воде кладенца, спушта главу у воду кладенац. Стајала је глава у кладенцу лепо време - четрдесет лета. А убаво на Косову тело: нит га једу орли и гаврани, нит га газе коњи ни јунаци. Мили Боже, на свем' теби хвала.

(...)

(...) 
Подигле се кириџије младе од убава бела града Скопља, они возе Грке и Бугаре, они иду Нишу и Видину, на Косову конак учинили. Вечерале кириџије младе, вечерале, пак су ожедниле; измећ' себе вењер ужегоше, ужегоше вењер јасну свећу, они траже воде по Косову, намера и намерила била, намерила на воду кладенца, један вели кириџија млади: „Ев’ у води месечине сјајне.” Други вели кириџија млади: „Није, браћо, месечина сјајна.” Трећи мучи, ништа не беседи, окрену се право ка истоку, па помену Бога истинога, ист'ног Бога и светог Николу: „Помоз, Боже, и оче Никола.” Па загази у воду кладенца: „Ово ј' глава једног господара.” Те извади из кладенца главу светитеља српскога Лазара, па је меће на зелену траву, и заити воде у кондиру. Док се жедни водом обредише, кад су црној земљи погледали, неста глава са зелене траве Скакала је Лазарева глава, скакала је по води Ситници, да не спазе Турии јаничари. Оде глава преко поља сама, света глава до светога тела, припоји се к'о што је и била. Кад ујутру бео дан освану глас дадоше кириџије младе, глас дадоше старим свештеником, и ту дође млого свештеника три стотине стари свештеника, и дванаест велики владика и четири стара патријара: прво пећки, друго цариградски, 
васељенски и јерусалимски;

облачише велике одежде,

и на главе капе камилавке,

и у руке књиге староставне, па чаташе велике молитве, и држаше велика денија.

Освећују светога Лазара

за три дана и три ноћи тавне

ни $m$ седоше, ни $m$ се одморише,

нит легоше, ни санка имаше,

моле свеца, куд ће светац поћи

да којој ће Лаза задужбини:

„Казуј јако Лазарева главо,

казуј јако на коју ћеш страну,

или Опову, или Крушедолу,

ил ћеш Јаску, или Бешеновој,

ил Раковцу, или Шишатовцу,

ил ћеш Ђипши, или Кувеждину,

да или ћеш у Маћедонију?

оној својој Раваници цркви,

коју јеси саградио Лазо,

саградио за живота свога,

да положиш своје чисто тело.

Неће светац задужбини туђој;

мртва глава али проговара:

„Ни Раковцу, ни Шишатовцу,

ни Опову, нити Крушедолу”,

већ он оће својој задужбини,

а у своју красну Раваницу

под високом, под Кучај планином,

што је Лаза саградио цркву

за живота јоште за својега,

саградио себи задужбину

о своме лебу и о своме благу,

а без суза сиротињскије. 